\title{
Isolates of 'Candidatus Nostocoida limicola' Blackall et al. 2000 should be described as three novel species of the genus Tetrasphaera, as Tetrasphaera jenkinsii sp. nov., Tetrasphaera vanveenii sp. nov. and Tetrasphaera veronensis sp. nov.
}

Correspondence

R. J. Seviour

r.seviour@latrobe.edu.au
C. M. McKenzie, ${ }^{1}$ E. M. Seviour, ${ }^{1}$ P. Schumann, ${ }^{2}$ A. M. Maszenan, ${ }^{1} \dagger$ J.-R. Liu, ${ }^{1} \ddagger$ R. I. Webb, ${ }^{3}$ P. Monis, ${ }^{4}$ C. P. Saint, ${ }^{4}$ U. Steiner ${ }^{2}$ and R. J. Seviour ${ }^{1}$

'Biotechnology Research Centre, La Trobe University, Bendigo, Victoria 3552, Australia

${ }^{2}$ DSMZ - Deutsche Sammlung von Mikroorganismen und Zellkulturen GmbH, Mascheroder Weg 1b, D-38124 Braunschweig, Germany

${ }^{3}$ Centre for Microscopy and Microanalysis, Department of Microbiology, The University of Queensland, St Lucia, Brisbane, Queensland 4072, Australia

${ }^{4}$ Australian Water Quality Centre, Bolivar, South Australia 5108, Australia

Despite differences in their morphologies, comparative analyses of $16 \mathrm{~S}$ rRNA gene sequences revealed high levels of similarity ( $>94 \%$ ) between strains of the filamentous bacterium 'Candidatus Nostocoida limicola' and the cocci Tetrasphaera australiensis and Tetrasphaera japonica and the rod Tetrasphaera elongata, all isolated from activated sludge. These sequence data and their chemotaxonomic characters, including cell wall, menaquinone and lipid compositions and fingerprints of their 16S-23S rRNA intergenic regions, support the proposition that these isolates should be combined into a single genus containing six species, in the family Intrasporangiaceae in the Actinobacteria. This suggestion receives additional support from DNA-DNA hybridization data and when partial sequences of the rpoC1 gene are compared between these strains. Even though few phenotypic characterization data were obtained for these slowly growing isolates, it is proposed, on the basis of the extensive chemotaxonomic and molecular evidence presented here, that 'Candidatus N. limicola' strains Ben 17, Ben 18, Ben 67, Ben 68 and Ben 74 all be placed into the species Tetrasphaera jenkinsii sp. nov. (type strain Ben $74^{\top}=\mathrm{DSM} 17519^{\top}=\mathrm{NCIMB} 14128^{\top}$ ), 'Candidatus N. limicola' strain Ben 70 into Tetrasphaera vanveenii sp. nov. (type strain Ben $70^{\top}=$ DSM $17518^{\top}=$ NCIMB $14127^{\top}$ ) and 'Candidatus N. limicola' strains Ver 1 and Ver 2 into Tetrasphaera veronensis sp. nov. (type strain Ver $1^{\top}=\mathrm{DSM} 17520^{\top}=\mathrm{NCIMB} 14129^{\top}$ ).
tPresent address: Environmental Engineering Research Centre, School of Civil and Environmental Engineering, Nanyang Technological University, Singapore.

$\ddagger$ Present address: Department of Chemistry and Biology, Ryerson University, Toronto, Ontario M5B 2K3, Canada.

Abbreviation: TFO, tetrad-forming organism.

The GenBank/EMBL/DDBJ accession numbers for the 16S rRNA gene sequences of strains Ben 68 , Ben 70 and Ben 74 are D0007319-DQ007321, respectively, and the accession numbers for the rpoC1 gene sequences determined in this study are D0007322D0007334, as detailed in Fig. 4.

Fatty acid profiles of selected strains of 'Candidatus N. limicola' and related strains are available in IJSEM Online.

\section{INTRODUCTION}

The application of molecular techniques has begun to resolve the taxonomic status of some of the bacteria present in activated sludge, especially those morphotypes which may often dominate the activated sludge bacterial community (Seviour et al., 2000; Martins et al., 2004). For example, some of the Gram-positive and Gram-negative filamentous bacteria responsible for the operational disorders of bulking and foaming have now been grown in pure culture and, on the basis of $16 \mathrm{~S}$ rRNA gene sequence data, their phylogeny has been elucidated (Kämpfer \& Wagner, 2002; Martins et al., 2004). Some, like 'Microthrix parvicella' (Blackall et al., 1994; Rossetti et al., 2005) and Eikelboom type 1851 (Beer et al., 2002), are novel bacteria, while others, like type 1863 
(Seviour et al., 1997), are close relatives of previously described non-filamentous bacteria. Of these filaments, 'Nostocoida limicola' is particularly interesting. Three morphotypes of this filament have been recognized, i.e. ' $N$. limicola' I, II and III, separated solely on the basis of differences in their cell dimensions (Eikelboom \& van Buijsen, 1983). It is now known that these morphotypes are in fact a collection of unrelated bacteria, being members of the Firmicutes (Liu et al., 2002), the Actinobacteria (Blackall et al., 2000), the Alphaproteobacteria (Snaidr et al., 2002; Levantesi et al., 2004; Kragelund et al., 2005) or the Chloroflexi (Schade et al., 2002) and the Planctomycetales (Liu et al., 2001). In the case of actinobacterial ' $N$. limicola' II, no chemotaxonomic data were available to help to delineate its taxonomic status precisely and that of the individual isolates obtained in pure culture and so, while the suggestion was made that this filament represented a new genus, it was given Candidatus status (Blackall et al., 2000).

The tetrad-forming organism (TFO) morphotype (Tsai \& Liu, 2002), appearing in activated sludge and pure cultures as cocci in tetrads and clusters, can dominate some activated sludge communities, and some of these TFO have been cultured and characterized. They include several novel Gram-positive and Gram-negative cocci (Seviour et al., 2000, 2003). Among these are members of the genus Tetrasphaera, now thought to be important populations responsible for the microbiological removal of phosphorus in some activated sludge processes (Kong et al., 2005). When $16 \mathrm{~S}$ rRNA gene sequences of cultured actinobacterial 'Candidatus Nostocoida limicola' isolates were compared with those from isolates of Tetrasphaera australiensis and Tetrasphaera japonica, Gram-positive TFO (Maszenan et al., 2000), these bacteria all clustered together at a high similarity. Although not possessing a TFO morphology, Tetrasphaera elongata (Hanada et al., 2002), which grows as rods, was also phylogenetically very similar. Therefore, attempts were made to clarify their taxonomic interrelationships using both 16S rRNA and rpoC1 gene sequences (Morse et al., 1996; Wilson et al., 2000) and detailed chemotaxonomic characterization. On the basis of all the available evidence, it is proposed that these 'Candidatus $\mathrm{N}$. limicola' isolates should all be placed into the genus Tetrasphaera and represent three novel species.

\section{METHODS}

Strains used in study. Isolates of actinobacterial 'Candidatus $\mathrm{N}$. limicola' (identified and cultured as ' $N$. limicola' II) and Tetrasphaera species, obtained and maintained as described by Blackall et al. (2000) and Maszenan et al. (2000), respectively (Table 1), were used in this study. They were grown on either GS or R2A agar (Blackall et al., 2000). Additional strains of 'Candidatus N. limicola' (Ben 70 and Ben 74) were also included in this study; these were isolated in our laboratory from other activated sludge biomass samples, by micromanipulation onto the same media used in the earlier study, and their sources are also listed in Table 1. The following cultures were also included in the rpoC1-based phylogenetic studies: Terrabacter tumescens DSM $20308^{\mathrm{T}}$ (Collins et al., 1989), Terracoccus luteus DSM $44267^{\mathrm{T}}$ (Prauser et al., 1997) and Janibacter limosus DSM $11140^{\mathrm{T}}$ (Martin et al., 1997).

Characterization of isolates. Selected substrate utilization patterns for strains Ben 70 and Ben 74 were obtained with the methods of Blackall et al. (2000), who had reported these for strains Ben 17, Ben 18, Ben 67 and Ver 1. The methods used for preparing specimens for scanning and transmission electron microscopy were those described by Maszenan et al. (1997, 1999) and Butler et al. (2002). The medium used to prepare the inoculum for each strain for characterization was that which supported its growth, since some isolates of 'Candidatus N. limicola' would grow only on R2A agar and not GS agar (Blackall et al., 2000). Biomass for chemotaxonomic characterization of selected strains was obtained by inoculating 200 plates of freshly prepared R2A agar (Reasoner \& Geldreich, 1985) for each isolate and incubating these at $26^{\circ} \mathrm{C}$ for exactly 4 weeks. Cells were harvested by gently scraping them from the agar surface into sterile distilled water, centrifuging and washing $(3 \times)$. These were finally freeze-dried. The 16S rRNA genes of the newly acquired isolates of 'Candidatus N. limicola' and Tetrasphaera were amplified, cloned and sequenced according to the methods of Maszenan et al. (2000) and Liu et al. (2002).

Sequences for the $r p o C 1$ genes from isolates were obtained as follows. Degenerate primers were designed after all publicly available $r p o C$ sequences in GenBank were aligned and edited with CLUSTAL W.

Table 1. Source of isolates used in this study

\begin{tabular}{|c|c|c|c|}
\hline Isolate & Source & Isolation medium & Reference \\
\hline Ben 17 & Sunbury, Australia & GS agar & Blackall et al. (2000) \\
\hline Ben 67 & Verona, Italy & $\mathrm{R} 2 \mathrm{~A}$ agar & Blackall et al. (2000) \\
\hline Ben 68 & Verona, Italy & R2A agar & Blackall et al. (2000) \\
\hline Ben 70 & Carrum, Australia & GS agar & R. J. Seviour (unpublished) \\
\hline \multicolumn{4}{|c|}{ Tetrasphaera australiensis } \\
\hline Ben $109^{\mathrm{T}}$ & Glenelg, Australia & GS agar & Maszenan et al. (2000) \\
\hline Ben 110 & Carrum, Australia & GS agar & Maszenan et al. (2000) \\
\hline \multicolumn{4}{|c|}{ Tetrasphaera japonica } \\
\hline $\mathrm{T} 1-\mathrm{X} 7^{\mathrm{T}}$ & Tokyo, Japan & Cell extract agar & Kataoka et al. (1996) \\
\hline
\end{tabular}


Primers eventually selected for PCR amplification of the rpoC1 gene were the forward primer $5^{\prime}$-TAYCGYCGKGTHATYAAYCG-3' and the reverse primer 5'-TGRTCACCRTCRAARTCRGC-3' (synthesized by Geneworks Pty Ltd, Adelaide, Australia); these primers gave a DNA fragment after PCR of approx. $600 \mathrm{bp}$. PCR was performed as described by Wilson et al. (2000). Thermal cycling conditions were a hot start at $95^{\circ} \mathrm{C}$ for $10 \mathrm{~min}$ followed by 30 cycles of $92^{\circ} \mathrm{C}$ for $1 \mathrm{~min}$, $42^{\circ} \mathrm{C}$ for $1 \mathrm{~min}$ and $72{ }^{\circ} \mathrm{C}$ for $3 \mathrm{~min}$, followed by $72{ }^{\circ} \mathrm{C}$ for $10 \mathrm{~min}$ and a final hold at $4{ }^{\circ} \mathrm{C}$. The PCR product was purified with QIAprep (Qiagen) and ligated into pGEM-T Easy vector (Promega). Clones were screened by restriction digestion with EcoRI and both DNA strands were sequenced with primers M13F and M13R. Sequencing was performed with Big Dye technology on a model 373A sequencer (Applied Biosystems). The 16S rRNA gene sequences for the other 'Candidatus N. limicola' isolates used in this study were those determined and reported by Blackall et al. (2000) and Maszenan et al. (2000), and sequences were also used that were reported in the original publications for Terracoccus luteus (Prauser et al., 1997), Terrabacter tumescens (Collins et al., 1989), Knoellia subterranea and Knoellia sinensis (Groth et al., 2002), Janibacter limosus (Martin et al., 1997), Janibacter anophelis (Kämpfer et al., 2006), Janibacter terrae (Yoon et al., 2000) and Janibacter melonis (Yoon et al., 2004), their closest phylogenetic relatives.

For both phylogenetic markers, the sequences were aligned using CLUSTAL X version 1.81 (Thompson et al., 1997). For rpoC1 analysis, 550 nucleotides equivalent to positions 302-852 of the Escherichia coli rpoC1 sequence were included in the alignment. For 16S rRNA gene analysis, 1426 nucleotides equivalent to positions 37-1463 of the E. coli $16 \mathrm{~S}$ rRNA sequence were included in the alignment. Phylogenetic analyses were conducted using MEGA2 version 2.1 (Kumar et al., 2001). Alignment files from CLUSTAL X were imported into MEGA2 and the data were analysed by distance-based and parsimony methods. For distance-based analyses, relationships were inferred using neighbourjoining analysis of Tamura-Nei distances that were calculated with the pairwise deletion option in effect. The robustness of the resulting phylogenies was tested using bootstrap analysis of 1000 replicates. For maximum-parsimony analyses, relationships were inferred using the close-neighbour-interchange search option with a search level of 3 and random addition of trees using 10 replications. All sites were included in each analysis and standard weighting was used for scoring changes. The robustness of the resulting phylogenies was tested using bootstrap analysis of 1000 replicates.

Chemotaxonomic characterization. The diastereoisomer of diaminopimelic acid in cell-wall hydrolysates of these isolates was determined with the HPLC method of McKerrow et al. (2000). Menaquinones were analysed by reversed-phase HPLC (Groth et al., 1999) and cellular fatty acid methyl esters and polar lipids were analysed using the methods of Schumann et al. (1997).

16S-23S rRNA intergenic spacer region fingerprinting. DNA was extracted from cultures as described by Liu et al. (2002) and the PCR primers selected to amplify this region were the primers 2 forward and 7 reverse of Gürtler \& Stanisich (1996). PCR conditions used were detailed by Liu et al. (2002). Restriction enzymes MspI and BstUI (New England Biolabs) were selected for digestion, and the digestion products were separated on agarose gels as described previously (Liu et al., 2002). Patterns were analysed using the $S_{\mathrm{SM}}$ coefficient and UPGMA algorithm.

DNA-DNA hybridizations. It was not possible to carry out DNADNA hybridization analysis with all these strains because of problems in obtaining sufficient quantities of biomass. Those analyses that were possible were performed following the methods used by Martin et al. (1997).
RESULTS

\section{Phenotypic properties of isolates}

As reported earlier (Blackall et al., 2000), all the isolates of 'Candidatus N. limicola' used in this study that could grow on GS agar grew as filamentous bacteria on this medium. Swollen and flattened discoid irregular cells within these filaments were common, as shown with strains Ben 67 and Ben 68 (Fig. 1e, f), and filaments were very similar to their appearance in biomass samples in activated sludge plants. Extensive irregular septation of some individual cells was also apparent (Fig. 1e, f), similar to that seen with Tetrasphaera elongata Lp2 ${ }^{\mathrm{T}}$ (Hanada et al., 2002). With R2A agar and broth, only rudimentary filamentous growth was seen. Instead, both strains Ben 17 and Ben 70 grew mainly as swollen and irregular cocci in very short chains or clusters (Fig. 1a, b). Budding was also visible, especially with strain Ben 70 (e.g. Fig. 1c). Intermediate forms with occasional swollen cocci in the filaments could also often be seen on GS medium (Fig. 1d-f).

The ultrastructural features of strains Ben 70 and Ben 74 grown on these two media are shown in Fig. 2. On R2A medium, both grew as irregular clusters of cells, although occasional short chains were seen (Fig. 2a-d). Cell shape was highly varied because of the erratic septation. This produces differently shaped and sized cells, which could be anything from coccoid to discoid. With strain Ben 74, the cells were often flattened and appeared more compressed than those of strain Ben 70 (Fig. 2a-d). Vesicles were commonly seen in both strains. Small vesicles appeared in tight clusters in cells. In Ben 74, several large electron-lucent vesicles were also present (Fig. 2c, d), while, in Ben 70, a single large vesicle that always contained electron-dense material was seen (Fig. 2a, b). Granules (30-40 $\mathrm{nm}$ diameter) were regularly seen in the cytoplasm of both strains. These often formed such dense aggregates that they led to the division of the cytoplasm into two distinct regions: electron-lucent (granule-filled) and electron-dense (containing all other cytoplasmic structures) (Fig. 2a-d). On GS agar, there appeared to be more empty cells in the chains than on R2A (Fig. 2h). Septation was not as random and hence the cells were largely in chains, though some irregular division caused chains of cells to split and clump (Fig. 2g, h). Narrow, compressed cells were present in both, but were seen more commonly with strain Ben 74, where flattened cells were routinely visible. Vesicles were not as common as in cells grown on R2A. In both strains, there were smaller vesicles of variable size clustered in the cytoplasm. In Ben 74, larger vesicles were also seen, and their size was often sufficient to distort the shape of the cells (Fig. 2h). Small, electron-dense granules were sparsely distributed through the cytoplasm of cells of both Ben 70 and Ben 74 grown on GS agar (Fig. 2g).

All cells showed a Gram-positive wall. This cell wall consisted of three visible layers: an inner electron-dense layer, which was closely associated with the cytoplasmic membrane, an electron-lucent layer and, on the outside, 

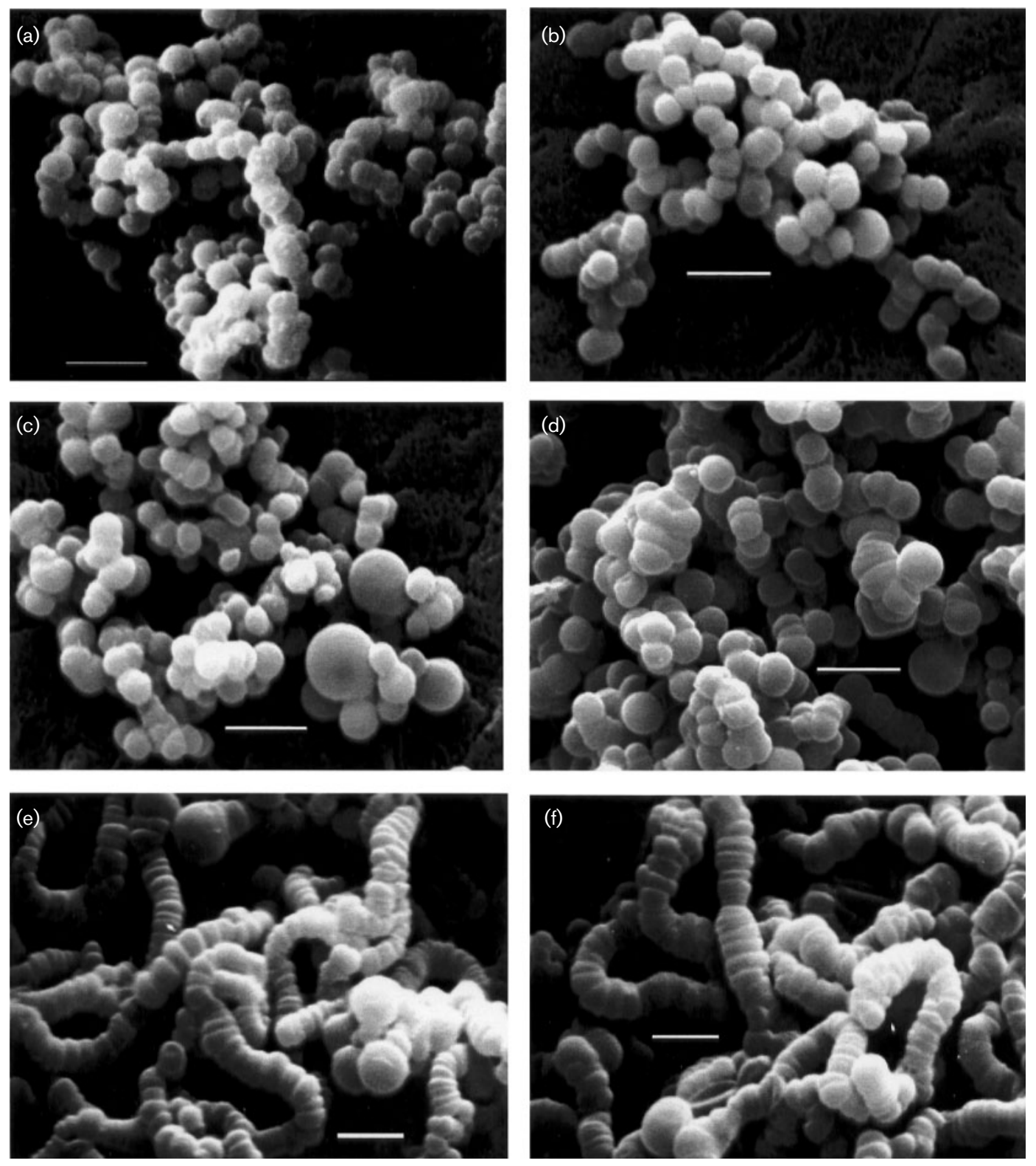

Fig. 1. Scanning electron micrographs of 'Candidatus $N$. limicola' strains grown on R2A agar (a-d) and GS agar (e, $f$ ), showing medium-dependent morphological variations. On R2A agar, strains Ben 17 (a) and Ben 70 (b) appear as regular cocci in clusters and short chains, although in Ben 70 (c) and Ben 74 (d), these cocci can appear inflated and in some cases appear to bud. On GS agar, strains Ben 67 (e) and Ben 68 (f) show typical features of all these strains on this medium of irregular flattened discoid cells in chains with occasional terminal swollen coccoid cells seen. Bars, $3 \mu \mathrm{m}(\mathrm{a}-\mathrm{d})$ and $4 \mu \mathrm{m}(\mathrm{e}, \mathrm{f})$.

another electron-dense layer (Fig. 2f). There were two layers of capsular material, an electron-lucent layer that surrounded each cell and an electron-dense layer that surrounded the entire cluster of cells (Fig. 2f). A thin strand of material from this outer capsule continued into the centre of the septum separating the cells. The dense capsule was much better developed in cells of Ben 70 and Ben 74 grown on GS agar than those on R2A.

In contrast to these 'Candidatus N. limicola' isolates, all three strains of Tetrasphaera examined, Tetrasphaera australiensis strains Ben $109^{\mathrm{T}}$ and Ben 110 and Tetrasphaera japonica $\mathrm{T} 1-\mathrm{X}^{\mathrm{T}}$, always grew as cocci in tetrads or clusters on all the media examined, and filamentous growth was never seen with them. On the other hand, Tetrasphaera elongata $\mathrm{Lp} 2^{\mathrm{T}}$ was reported to grow as rods or oval unicells (Hanada et al., 2002).

Because of their very slow growth rates in pure culture (Blackall et al., 2000), extensive phenotypic characterization of these 'Candidatus N. limicola' isolates was not always possible, experiences that agree with those reported earlier 

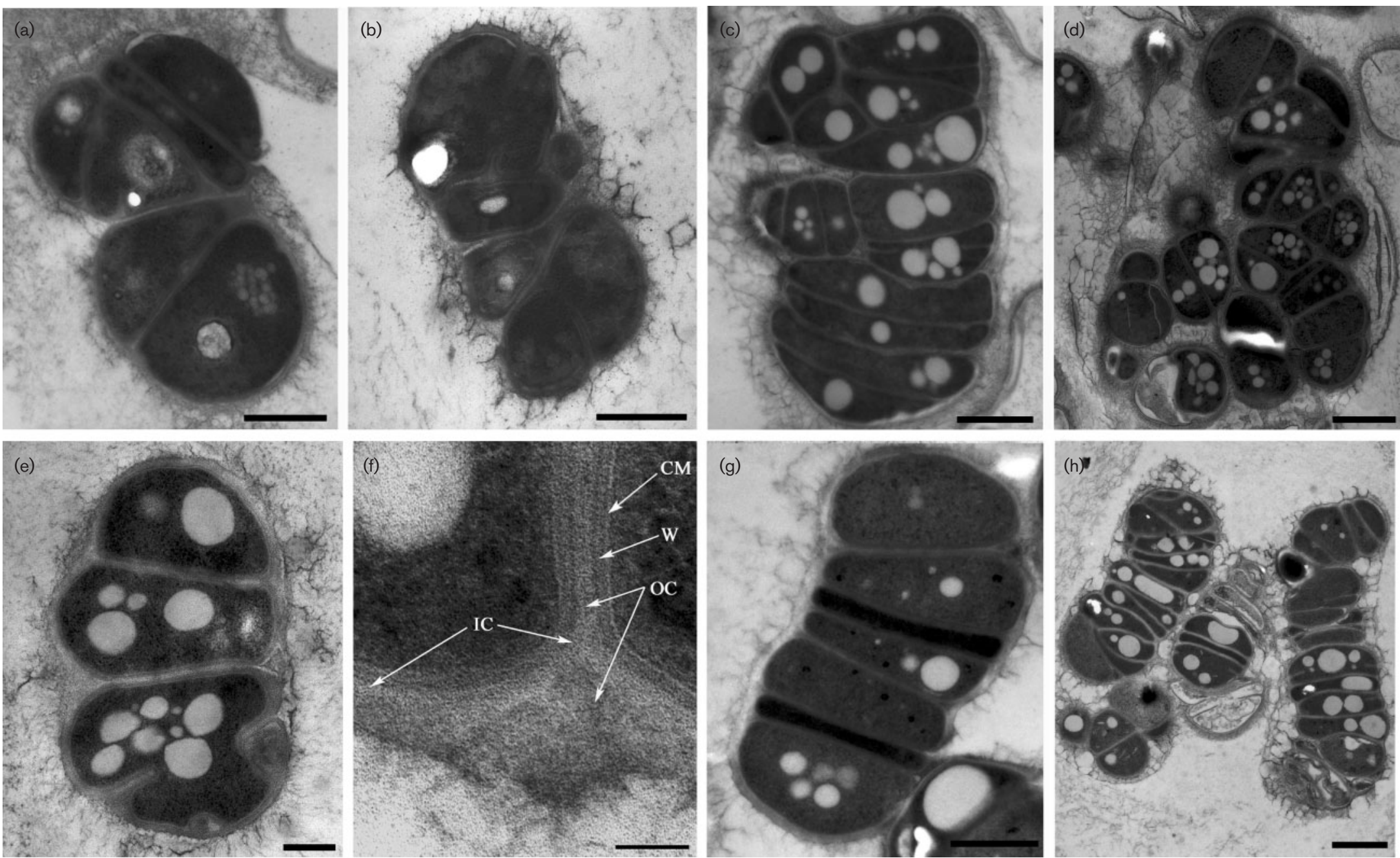

Fig. 2. Transmission electron micrographs of cell ultrastructure of strains of 'Candidatus N. limicola'. (a, b) Strain Ben 70 grown on R2A agar shows capsular materia surrounding short chains (a) or irregular clusters of cells (b). Randomly orientated septation is clearly apparent. Cells contain tight groups of small vesicles and a single large vesicle with electron-dense material. Aggregates of electron-lucent granules appear in the cytoplasm. Bars, $500 \mathrm{~nm}$. (c, d) Strain Ben 74 grown on R2A shows many features described for strain Ben 70, except that cells in groups are more compressed. Larger, clear vesicles are present. Bars, $1 \mu \mathrm{m}$. (e, f) Strain Ben 70 grown on GS agar shows most cells in irregular chains. Vesicles of varying sizes are generally distributed more randomly through the cytoplasm (e). The arrangement of the three-layered Gram-positive wall (W) lying outside the cytoplasmic membrane (CM) is visible in (f). The capsular material is divided into two distinct regions, the inner (IC) closely associated with the cells and the outer electron-dense (OC) that surrounds the clumps and is also seen as a strand in the centre of the dividing septum. Bars, $200 \mathrm{~nm}(\mathrm{e}$ ) and $50 \mathrm{~nm}(\mathrm{f}) .(\mathrm{g}, \mathrm{h})$ Strain Ben 74 grown on GS agar shows most of the features of strain Ben 70, especially the growth in chains and the same random septation, but cells appear more compressed. Bars, $500 \mathrm{~nm}(\mathrm{~g})$ and $1 \mu \mathrm{m}(\mathrm{h})$. 
by Blackall et al. (2000). However, some biochemical characteristics of strains Ben 17, Ben 67 and Ver 1 were reported by Blackall et al. (2000). They were very similar in all three strains, except that Ver 1 alone could not grow with nitrite as sole nitrogen source. When Ben 70 and Ben 74 were characterized in the same way, both showed very similar patterns to these other isolates. Thus all grew on acetate, pyruvate, propionate, glucose, fructose, lactose, mannose, Tween 80 and glycerol as carbon sources and nitrate, nitrite and urea as nitrogen sources. Like the other strains examined, neither could utilize lactate, ethanol, oleic acid or oleate. All contained both poly- $\beta$-hydroxyalkanoates and polyphosphate granules by staining. All were catalase- and oxidase-positive, as are Tetrasphaera australiensis Ben $109^{\mathrm{T}}$ and Tetrasphaera japonica $\mathrm{T} 1-\mathrm{X} 7^{\mathrm{T}}$. However, Tetrasphaera australiensis Ben 110 and Tetrasphaera elongata $\mathrm{Lp} 2^{\mathrm{T}}$ are both oxidase-negative (Maszenan et al., 2000; Hanada et al., 2002), which may be an artefact reflecting their generally low levels of metabolic activity.

\section{Chemotaxonomic features of isolates}

These characters are summarized in Table 2, and could be determined only for selected strains of 'Candidatus N. limicola', where sufficient biomass for the analyses could be obtained. Cell walls of all the isolates examined (strains Ben 17, Ben 70, Ben 74 and Ver 1) had meso-diaminopimelic acid as the dibasic amino acid (i.e. type $\mathrm{Al} \gamma$ peptidoglycan), as did Tetrasphaera australiensis strains Ben $109^{\mathrm{T}}$ and Ben 110 and Tetrasphaera japonica $\mathrm{T} 1-\mathrm{X} 7^{\mathrm{T}}$ (Maszenan et al., 2000) and Tetrasphaera elongata $\mathrm{Lp}^{\mathrm{T}}$ (Hanada et al., 2002). For both strains Ben 17 and Ben 74, the menaquinones were MK-8 $\left(\mathrm{H}_{4}\right)$, MK- $8\left(\mathrm{H}_{2}\right)$, MK-8 and MK-6( $\left.\mathrm{H}_{4}\right)$, in ratios of $87: 5: 3: 2$ and $80: 3: 4: 5$, respectively. However, several attempts failed to detect menaquinones or ubiquinones in Ver 1 by HPLC/mass spectrometry, although similar quantities of biomass as for the other strains were used for their extraction. Strain Ben 70 was distinct in containing MK-8, MK- $8\left(\mathrm{H}_{2}\right)$ and MK-8 $\left(\mathrm{H}_{4}\right)$, in the ratio of $39: 29: 6$. Polar lipid profiles of these strains were dominated by diphosphatidylglycerol, phosphatidylglycerol and phosphatidylinositol, except Ben 17 and Ben 74, which did not possess diphosphatidylglycerol (Table 2). Phosphatidylethanolamine was detected only in Ben 110 and Tetrasphaera elongata $\mathrm{Lp} 2^{\mathrm{T}}$, but an unidentified aminophospholipid was present in Ben 17, Ben 70, Ben 74, Ver 1 and Tetrasphaera japonica $\mathrm{T} 1-\mathrm{X} 7^{\mathrm{T}}$.

Fatty acid profiles of strains Ben 17, Ben 70, Ben 74 and Ver 1, together with those from Tetrasphaera australiensis strains Ben $109^{\mathrm{T}}$ and Ben 110, Tetrasphaera japonica $\mathrm{T} 1-\mathrm{X}^{\mathrm{T}}$ and Tetrasphaera elongata $\mathrm{Lp}^{\mathrm{T}}$ (Maszenan et al., 2000; Hanada et al., 2002), are given in Supplementary Table S1 in IJSEM Online. 14-Methylpentadecanoic acid $\left(\mathrm{i}-\mathrm{C}_{16: 0}\right)$ dominated in all these strains, including the Tetrasphaera strains except for Tetrasphaera elongata $\mathrm{Lp}^{\mathrm{T}}{ }^{\mathrm{T}}$ (Hanada et al., 2002). This strain alone possessed ai- $\mathrm{C}_{15: 0}$ as the major fatty acid. Strain Ben 17 contained more 14-methylhexadecanoic acid (ai$\mathrm{C}_{17: 0}$ ) than any of the other strains (Supplementary
Table S1). Qualitative and quantitative differences were apparent among the 'Candidatus N. limicola' strains. Only strain Ben 74 possessed small amounts of octadecanoic acid $\left(\mathrm{C}_{18: 0}\right)$, 9-heptadecenoic acid $\left(\mathrm{C}_{17: 1}\right)$ and 16methylheptadecanoic acid $\left(\mathrm{i}-\mathrm{C}_{18: 0}\right)$, while strain Ver 1 alone lacked 9-octadecenoic acid $\left(\mathrm{C}_{18: 1}\right)$, 15methylhexadecanoic acid (i- $\left.\mathrm{C}_{17: 0}\right)$ and 15-methyl-9hexadecenoic acid $\left(\mathrm{i}-\mathrm{C}_{17: 1}\right)$. These fatty acid profiles were also markedly different quantitatively from those of the characterized Knoellia and Janibacter strains (as given in Supplementary Table S1 in IJSEM Online), especially since $\mathrm{i}-\mathrm{C}_{16: 0}$ is not as prominent, adding weight to the view that the strains described here are all members of the one genus, Tetrasphaera.

\section{Phylogenetic analyses}

Almost-complete sequences of the 16S rRNA genes from 'Candidatus N. limicola' strains Ben 70 (1473 bp) and Ben 74 (1477 bp) were obtained and analysed with those from the other 'Candidatus N. limicola' and Tetrasphaera isolates described earlier by Blackall et al. (2000), Maszenan et al. (2000) and Hanada et al. (2002). Parsimony analysis identified three trees of equal length, one of which had an identical topology to that of the distance-based phylogenetic tree illustrated in Fig. 3. The other two trees differed only in the branch orders of species outside the clade containing the 'Candidatus N. limicola' isolates (data not shown). Sequences from strains Ben 17, Ben 18, Ben 67, Ben 68 and Ben 74 were all $>99 \%$ similar to each other and formed a well-defined and separate cluster supported by high bootstrap values $(\geqslant 98 \%)$ for both analyses. Their sequences were all $97-98 \%$ similar to those of strains Ver 1 and Ben 70, which in turn were $97 \%$ similar to each other. Strain Ben 70 and Tetrasphaera australiensis strains Ben $109^{\mathrm{T}}$ and Ben 110 were more closely related to each other than either was to Tetrasphaera japonica $\mathrm{T} 1-\mathrm{X}^{\mathrm{T}}$ and Tetrasphaera elongata $\mathrm{Lp} 2^{\mathrm{T}}$. Only strains Ver 1 and Ver 2 of these 'Candidatus N. limicola' strains had the distinctive V6 region sequence variation noted by Blackall et al. (2000) for this filament. None of Tetrasphaera japonica $\mathrm{T} 1-\mathrm{X} 7^{\mathrm{T}}$, Tetrasphaera australiensis strains Ben $109^{\mathrm{T}}$ and Ben 110 or Tetrasphaera elongata $\mathrm{Lp} 2^{\mathrm{T}}$ possessed it.

The rpoC1 analysis (Fig. 4) did not provide the same level of resolution as the 16S rRNA gene analysis. The distancebased analysis (Fig. 4) produced a tree with a similar topology to the 16S rRNA tree for the "Candidatus N. limicola' and Tetrasphaera australiensis isolates. 'Candidatus N. limicola' isolates Ben 17, Ben 18, Ben 67, Ben 68 and Ben 74 again formed a single cluster that received strong bootstrap support. However, the internal branch order, which received poor bootstrap support, was different from that seen with the 16S rRNA gene sequence results. 'Candidatus N. limicola' isolate Ben 70 also clustered with Tetrasphaera australiensis with moderate bootstrap support and 'Candidatus N. limicola' strain Ver 1 was placed as a sister taxon to this group, which is different from the topology of the 16S rRNA gene tree. The clustering of Ben 70 
Table 2. Phenotypic and chemotaxonomic characters of strains of 'Candidatus N. limicola', Tetrasphaera species and related genera

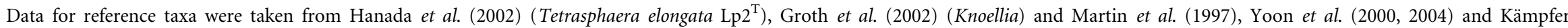

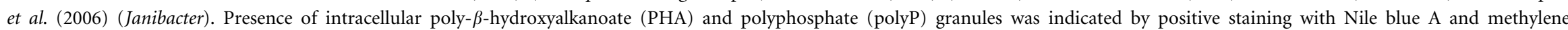
blue, respectively (Blackall et al., 2000). ND, Not determined; NR, not reported; v, varies (depending on strain and medium); w, weak. Major components are indicated in bold.

\begin{tabular}{|c|c|c|c|c|c|c|c|c|c|}
\hline Character & $\begin{array}{l}\text { T. elongata } \\
\qquad \mathrm{Lp} 2^{\mathrm{T}}\end{array}$ & $\begin{array}{l}\text { T. australiensis } \\
\text { Ben } 109^{T}\end{array}$ & $\begin{array}{c}\text { s. australiensis } \\
\text { Ben } 110\end{array}$ & $\begin{array}{l}\text { T. japonica } \\
\text { T1-X7 }\end{array}$ & $\begin{array}{l}\text { T. veronensis } \\
\operatorname{Ver} 1^{\mathrm{T}}\end{array}$ & $\begin{array}{l}\text { T. jenkinsii } \\
\text { Ben } 17, \\
\text { Ben } 74^{\mathrm{T}}\end{array}$ & $\begin{array}{l}\text { T. vanveenii } \\
\text { Ben } 70^{T}\end{array}$ & Knoellia & Janibacter \\
\hline Cell morphology & $\begin{array}{l}\text { Oval to } \\
\text { rod-shaped }\end{array}$ & Always cocci & Always cocci & Always cocci & $\begin{array}{l}\text { Filaments on GS. } \\
\text { Cocci/discoid } \\
\text { cells on R2A. } \\
\text { Irregular septate } \\
\text { cells common }\end{array}$ & $\begin{array}{l}\text { Filaments on GS. } \\
\text { Cocci/discoid } \\
\text { cells on R2A. } \\
\text { Irregular septate } \\
\text { cells common }\end{array}$ & $\begin{array}{l}\text { Filaments on GS. } \\
\text { Cocci on R2A }\end{array}$ & $\begin{array}{l}\text { Cocci in different } \\
\text { arrangements in } \\
\text { stationary phase, } \\
\text { giving rise to } \\
\text { irregular rods } \\
\text { on fresh medium }\end{array}$ & $\begin{array}{l}\text { Cocci or short } \\
\text { rods in chains } \\
\text { or aggregates }\end{array}$ \\
\hline Oxidase & - & + & $\mathrm{W}$ & + & + & + & + & - & $\mathrm{W}$ \\
\hline PHA production & - & - & - & - & + & + & + & NR & NR \\
\hline polyP production & + & + & + & + & + & + & + & NR & NR \\
\hline $\begin{array}{l}\mathrm{G}+\mathrm{C} \text { content } \\
\quad(\mathrm{mol} \%)\end{array}$ & 70 & 70 & 68 & 71 & ND & ND & ND & $68-69$ & $69-73$ \\
\hline Menaquinones & MK-8 $\left(\mathrm{H}_{4}\right)$ & $\begin{array}{l}\text { MK-8 }\left(\mathbf{H}_{4}\right), \\
\text { MK-8 }\left(\mathrm{H}_{2}\right), \\
\text { MK-8 }\end{array}$ & $\begin{array}{l}\text { MK-8 }\left(\mathbf{H}_{4}\right) \\
\text { MK-6 }\left(\mathrm{H}_{4}\right) \\
\text { MK-8( }\left(\mathrm{H}_{2}\right)\end{array}$ & $\begin{array}{l}\text { MK-8 }\left(\mathrm{H}_{4}\right) \\
\text { MK-7 }\left(\mathrm{H}_{4}\right) \\
\text { MK-6 }\left(\mathrm{H}_{4}\right)\end{array}$ & None detected & $\begin{array}{c}\left.\text { MK-8 }\left(\mathbf{H}_{4}\right), \text { MK-6( } \mathrm{H}_{4}\right) \\
\text { MK-8 }\left(\mathrm{H}_{2}\right), \text { MK-8 }\end{array}$ & $\begin{array}{l}\text { MK-8, MK-8 }\left(\mathrm{H}_{2}\right) \\
\quad \mathrm{MK}-8\left(\mathrm{H}_{4}\right)\end{array}$ & $\begin{array}{l}\text { MK-8 }\left(\mathrm{H}_{4}\right) \\
\text { MK-7 }\left(\mathrm{H}_{4}\right) \\
\text { MK-6 }\left(\mathrm{H}_{4}\right)\end{array}$ & $\begin{array}{c}\text { MK-8 }\left(\mathbf{H}_{\mathbf{4}}\right) \\
\text { (where reported) }\end{array}$ \\
\hline Major fatty acids & $\begin{array}{l}\text { ii- } C_{15: 0}, i-C_{15: 0} \\
\quad \text { i- } C_{14: 0}\end{array}$ & $\begin{array}{l}\text { i- } \mathbf{C}_{\mathbf{1 6}} \text { : } \\
\text { ai- } \mathrm{C}_{17: 0} \\
\mathrm{i}-\mathrm{C}_{15: 0}\end{array}$ & $\begin{array}{c}\text { i- } C_{16: 0}, \text { ai }-C_{17: 0}, \\
\text { i- } C_{16: 1}\end{array}$ & $\mathrm{i}-\mathrm{C}_{16: 0}$, ai- $\mathrm{C}_{17: 0}$ & $\begin{array}{c}\mathrm{i}-\mathrm{C}_{16: 0}, \mathrm{i}-\mathrm{C}_{16: 1}, \\
\mathrm{i}-\mathrm{C}_{15: 0}\end{array}$ & $\begin{array}{c}\text { ai- } C_{17: 0}, \text { i- } C_{16: 0}, \\
i-C_{15: 0}, i-C_{16: 1}\end{array}$ & $\mathrm{i}-\mathrm{C}_{16: 0}, \mathrm{i}-\mathrm{C}_{15: 0}$ & $\begin{array}{c}\text { i- } C_{17: 1}, \mathbf{i}-C_{15: 0} \\
\text { i- } C_{16: 0}, i-C_{17: 0} \\
\text { ai- } C_{17: 0}\end{array}$ & $\begin{array}{l}\mathrm{V}\left(\mathrm{i}-\mathrm{C}_{16: 0}, \mathrm{C}_{17: 1},\right. \\
\left.\mathrm{C}_{17: 0}, \mathrm{C}_{18: 1}\right)\end{array}$ \\
\hline Polar lipids* & $\begin{array}{c}\text { DPG, PG, PI, } \\
\text { PE }\end{array}$ & $\begin{array}{l}\text { DPG, PG, } \\
\text { PI, PL }\end{array}$ & DPG, PG, PI, PE & $\begin{array}{c}\text { DPG, PG, } \\
\text { PI, PL, APL }\end{array}$ & DPG, PI, PG, APL & PI, PG, APL & PG, DPG, PI, APL & $\begin{array}{c}\text { PE, PI, } \\
\text { DPG, PG }\end{array}$ & DPG, PG, PI \\
\hline
\end{tabular}

${ }^{\star}$ APL, Unknown aminophospholipid; DPG, diphosphatidylglycerol; PE, phosphatidylethanolamine; PG, phosphatidylglycerol; PI, phosphatidylinositol; PL, unknown phospholipid. 


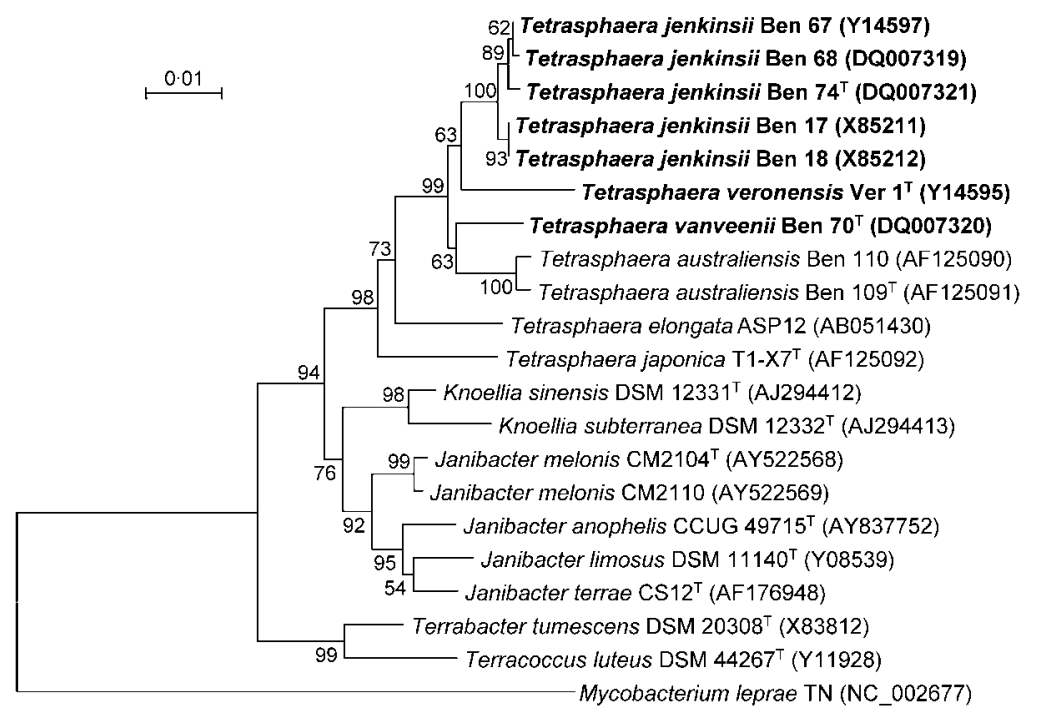

Fig. 3. Phylogenetic analysis of $16 \mathrm{~S}$ rRNA gene sequences of 'Candidatus N. limicola' strains (in bold) and their nearest relatives based on $1420 \mathrm{bp}$, after neighbour-joining analysis using Tamura-Nei distance estimates. Nodes receiving $\geqslant 50 \%$ bootstrap support (1000 replicates) are indicated. Bar, 0.01 nucleotide substitutions per site.

with the Tetrasphaera australiensis strains was recovered in nine of the parsimony trees (data not shown). The 'Candidatus N. limicola' and Tetrasphaera australiensis isolates formed a cluster consistent with that in the $16 \mathrm{~S}$ rRNA gene sequence results, but in this case there was no bootstrap support for the grouping. The rest of the tree topology (with the exception of the placement of the outgroups) received poor bootstrap support, and was different from the $16 \mathrm{~S}$ rRNA gene tree topology. Tetrasphaera elongata $\mathrm{Lp} 2^{\mathrm{T}}$ was not included in this analysis.

\section{S-23S rRNA intergenic fingerprinting}

The fingerprints obtained after restriction digestion of this region with the two enzymes showed that strains Ben 17, Ben 18, Ben 67, Ben 68 and Ben 74 gave identical patterns after digestion with MspI (Fig. 5a), while strain Ben 70 was quite

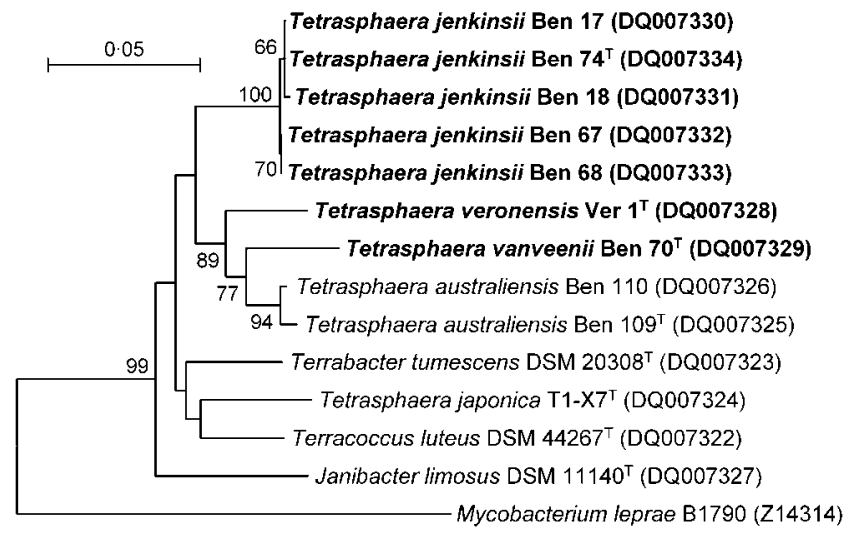

Fig. 4. Phylogenetic analysis of rpoC1 DNA sequences of 'Candidatus N. limicola' strains (in bold) and their closest relatives based on $600 \mathrm{bp}$ and neighbour-joining analysis using Tamura-Nei distance estimates. Nodes receiving $\geqslant 50 \%$ bootstrap support (1000 replicates) are indicated. Bar, 0.05 nucleotide substitutions per site. different, sharing only two bands with these other strains. Strain Ver 1 was also different, having two bands in common with the 'strain Ben 17' group and one band in common with strain Ben 70, as well as possessing a single band not
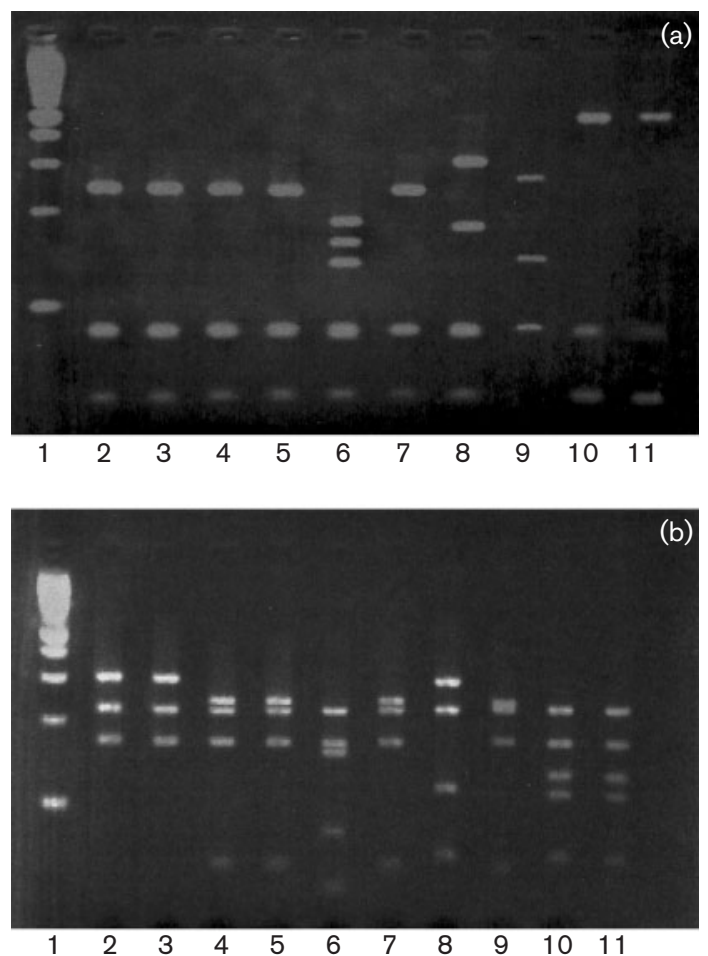

Fig. 5. Fingerprints of the $16 \mathrm{~S}-23 \mathrm{~S}$ rRNA intergenic spacer region of strains of 'Candidatus N. limicola' and Tetrasphaera species after digestion with the restriction endonucleases $\mathrm{Mspl}$ (a) and BstUI (b) and separation by agarose gel electrophoresis. Lanes: 1, $100 \mathrm{bp}$ molecular marker; 2, Ben 17; 3, Ben 18; 4, Ben 67; 5, Ben 68; 6, Ben 70; 7, Ben 74; 8, Ver 1; 9, Tetrasphaera japonica $\mathrm{T} 1-\mathrm{X} 7^{\top} ; 10$, Tetrasphaera australiensis Ben 109 ${ }^{\top} ; 11$, Tetrasphaera australiensis Ben 110. 
seen in any of the other isolates. The patterns from Tetrasphaera australiensis strains Ben $109^{\mathrm{T}}$ and 110 were identical to each other, possessing a unique band. They had two bands in common with all the other strains except Tetrasphaera japonica $\mathrm{T} 1-\mathrm{X}^{\mathrm{T}}$ (where only one common band could be seen). This strain also shared this band with all other strains and had two bands in common with strain Ben 70 , while one was unique to it.

The patterns generated with the enzyme BstUI suggested slightly different relationships between these strains (Fig. 5b). Thus, even though strains Ben 17 and Ben 18 again gave identical patterns with this enzyme, strains Ben 67, Ben 68 and Ben 74, although identical to each other, now shared only two of four bands with them. Strain Ben 70 was again quite different, possessing three bands not seen in the others, although two of its other bands were common to all other strains. The pattern of strain Ver 1 was also distinctive, sharing only two bands with strains Ben 17 and Ben 18 and one with strains Ben 67, Ben 68, Ben 70 and Ben 74. Again, Tetrasphaera australiensis strains Ben $109^{\mathrm{T}}$ and Ben 110 gave identical patterns, possessing two unique bands and two bands in common with all other strains except strain Ver 1, with which it shared only a single band. Tetrasphaera japonica $\mathrm{T} 1-\mathrm{X}^{\mathrm{T}}$ gave a distinctive pattern, with one unique band, one band shared with all the other strains, another in common with all except strain Ver 1 and another shared only with strains Ben 67, Ben 68 and Ben 74. A dendrogram (not shown) obtained after numerical analysis of 23 characters from these patterns revealed that strains Ben 17, Ben 18, Ben 67, Ben 68 and Ben 74 formed a single cluster at $0.86 S_{\mathrm{SM}}$, while the patterns of the other strains and those of Tetrasphaera australiensis and Tetrasphaera japonica T1$\mathrm{X} 7^{\mathrm{T}}$ emerged as quite different from each other. Thus, strain Ver 1 was closer to Tetrasphaera australiensis than it was to the other ' $N$. limicola' II isolates analysed.

\section{DNA-DNA hybridization data}

Previous DNA-DNA hybridization data showed that Tetrasphaera australiensis strains Ben $109^{\mathrm{T}}$ and 110 and T. japonica $\mathrm{T} 1-\mathrm{X} 7^{\mathrm{T}}$ represent two separate genomic species (Maszenan et al., 2000). DNA-DNA hybridization values could be obtained between only some of the strains examined in this present study. Strains Ben 17 and Ben 74 had a DNA-DNA relatedness value of $74 \%$, Ben 74 and Ben 67 were $70 \%$ related, while the DNA-DNA hybridization value between Ben 74 and Ver 1 was only $17 \%$. The DNADNA hybridization values determined between Tetrasphaera australiensis Ben $109^{\mathrm{T}}$ and strains Ben 70 , Ver 1, Ben 67 and Ben 74 were respectively $46.9 \%$ (mean of duplicates), $39 \cdot 7,33 \cdot 1$ and $14 \cdot 2 \%$.

\section{DISCUSSION}

The chemotaxonomic and phylogenetic data presented here suggest that all of the 'Candidatus N. limicola' strains examined belong to a single genus. The question then remains as to whether these 'Candidatus N. limicola' isolates represent a new genus or are members of any of the existing genera Tetrasphaera, Knoellia or Janibacter, their closest phylogenetic relatives (Fig. 3). No taxonomic decisions were possible in the earlier study with 'Candidatus N. limicola' (Blackall et al., 2000) in the absence of important chemotaxonomic data, because of their very slow growth rates and the consequent problems of obtaining sufficient biomass for analyses. The 16S rRNA gene sequence data (Fig. 3) show that the Tetrasphaera and 'Candidatus N. limicola' isolates form clusters supported by high bootstrap values, which are quite separate from the type strains of J. limosus, J. terrae, J. melonis, J. anophelis, K. sinensis, K. subterranea, Terrabacter tumescens and Terracoccus luteus (Fig. 3). The phylogenetic closeness of all these 'Candidatus N. limicola' strains (especially strains Ben 17, Ben 18, Ben 67, Ben 68 and Ben 74) to the existing Tetrasphaera species is substantiated when $r p o C 1$ gene sequence data are analysed from the same group of bacteria (Fig. 4), and these too are generally consistent with them all belonging to a single genus. Some differences were seen compared with the groupings that emerged from 16S rRNA gene sequence analyses (most notably with strains Ben 70 and Ver 1 now clustering most closely), despite claims that $r p o C 1$ sequence data generally provide phylogenetic support for groupings from 16S rRNA gene sequence data (Morse et al., 1996; Seo \& Yokota, 2003). It has also been claimed, at least with the cyanobacteria, that $r p o C 1$ sequence data are able to resolve genus-species relationships better than 16S rRNA gene sequence data can (Wilson et al., 2000; Fergusson \& Saint, 2000).

Chemotaxonomic data obtained from strains Ben 17, Ben 74, Ben 70 and Ver 1 (chosen for analysis as representing members of the main clusters revealed after the 16S rRNA gene sequence analyses) showed them all to have the Al $\gamma$ cell-wall type, and all except Ver 1 contained $\mathrm{MK}-8\left(\mathrm{H}_{4}\right)$ as a major menaquinone. These chemical features are shared by members of the genera Tetrasphaera (Maszenan et al., 2000), Janibacter (Martin et al., 1997; Yoon et al., 2000, 2004; Kämpfer et al., 2006) and Knoellia (Groth et al., 2002) and distinguish them from all other currently described close relatives, including members of the genus Terrabacter and Terracoccus, both of which possess the A3 $\gamma$ cell-wall type (Maszenan et al., 2000). Comparisons of their polar lipid and fatty acid compositions (Supplementary Table S1) suggest that the 'Candidatus N. limicola' isolates are also more similar to Tetrasphaera australiensis strains, Tetrasphaera japonica $\mathrm{T} 1-\mathrm{X} 7^{\mathrm{T}}$ and Tetrasphaera elongata $\mathrm{Lp} 2^{\mathrm{T}}$ (Maszenan et al., 2000; Hanada et al., 2002) than to species of either Janibacter or Knoellia (Supplementary Table S1).

The problem of speciation then needs to be addressed. The 16S rRNA gene, $r p o C 1$ and 16S-23S rRNA intergenic spacer region fingerprints together suggest that six species are present in this group of bacteria, i.e. the pre-existing Tetrasphaera australiensis, Tetrasphaera japonica (Maszenan et al., 2000) and Tetrasphaera elongata (Hanada et al., 2002) 
and three novel ones consisting of strains Ben 17, Ben 18, Ben 67 and Ben 74, strain Ben 70 and strain Ver 1. The available DNA-DNA hybridization data support this. Furthermore, strain Ver 1 was the only 'Candidatus N. limicola' isolate among these strains to possess the distinctive nucleotide sequence variation in the V6 region of the 16S rRNA gene that was noticed by Blackall et al. (2000). Ben 70 is different from the other isolates in having MK-8 and MK-8 $\left(\mathrm{H}_{2}\right)$ as its major menaquinones, while no menaquinones could be detected in strain Ver 1, despite repeated analyses. Thus, when these menaquinone profiles are considered, strains Ben 70 and Ver 1 appear to belong to separate species. Strains Ben 17, Ben 18, Ben 67, Ben 68 and Ben 74 share nearly identical 16S rRNA gene and rpoC1 sequences, and their 16S-23S rRNA intergenic fingerprints are either identical or very similar, depending on the restriction endonuclease used. The DNA-DNA hybridization values of 74 and $70 \%$, respectively, for Ben 17 versus Ben 74 and Ben 67 versus Ben 74 are consistent with these other observations. Thus, by association, these strains and Ben 18 and Ben 68 are all considered to belong to the same genomic species. Although not subjected to some of the characterizations described here, Tetrasphaera elongata $\mathrm{Lp} 2^{\mathrm{T}}$ is considered a separate species on the basis of its previous description (Hanada et al., 2002), especially its fatty acid composition, which contains distinctively high levels of ai- $\mathrm{C}_{15: 0}$ and low levels of $\mathrm{i}-\mathrm{C}_{16: 0}$ (Hanada et al., 2002).

Therefore, we propose that these isolates of 'Candidatus $\mathrm{N}$. limicola' (Ben 17, Ben 18, Ben 67, Ben 68, Ben 70, Ben 74 and Ver 1) be combined with Tetrasphaera elongata, Tetrasphaera australiensis and Tetrasphaera japonica in the genus Tetrasphaera. On the basis of the characterization data presented here, we propose that strains Ben 17, Ben 18, Ben 67 , Ben 68 and Ben $74^{\mathrm{T}}$ be assigned to a single species as Tetrasphaera jenkinsii sp. nov. These data also support the designation of strain Ben $70^{\mathrm{T}}$ to a novel species Tetrasphaera vanveenii sp. nov. and strains $\operatorname{Ver} 1^{\mathrm{T}}$ and Ver 2 to Tetrasphaera veronensis sp. nov.

\section{Description of Tetrasphaera jenkinsii sp. nov.}

Tetrasphaera jenkinsii (jen.kin'si.i. N.L. gen. n. jenkinsii of Jenkins, referring to David Jenkins, a contemporary American environmental engineer, who has made a considerable contribution to our understanding of the filamentous bacteria causing bulking and foaming in activated sludge processes).

The phenotypic features of this species are those given by Blackall et al. (2000) for 'Candidatus N. limicola' strains Ben 17, Ben 18, Ben 67, Ben 68 and Ben 74, supplemented by the results of this study as follows. Poly- $\beta$-hydroxyalkanoate and polyphosphate production is positive. Major menaquinone is $\mathrm{MK}-8\left(\mathrm{H}_{4}\right)$, while MK-6( $\left.\mathrm{H}_{4}\right), \mathrm{MK}-8$ and $\mathrm{MK}-8\left(\mathrm{H}_{2}\right)$ occur in minor amounts. Present members of the species were isolated from activated sludge systems in Australia.
The type strain is Ben $74^{\mathrm{T}}\left(=\mathrm{DSM} 17519^{\mathrm{T}}=\mathrm{NCIMB}\right.$ $\left.14128^{\mathrm{T}}\right)$.

\section{Description of Tetrasphaera vanveenii sp. nov.}

Tetrasphaera vanveenii (van.vee' ni.i. N.L. gen. n. vanveenii of van Veen, referring to the late Dutch microbiologist W. L. van Veen, who originally isolated this filamentous bacterium from activated sludge).

The phenotypic features of this species are those given by Blackall et al. (2000) for 'Candidatus N. limicola' strain Ben 70 , supplemented by the results of this study as follows. Poly- $\beta$-hydroxyalkanoate and polyphosphate production is positive. Menaquinones are $\mathrm{MK}-8, \mathrm{MK}-8\left(\mathrm{H}_{2}\right)$ and $\mathrm{MK}-$ $8\left(\mathrm{H}_{4}\right)$. The polar lipid pattern contains diphosphatidylglycerol and an unidentified aminophospholipid.

The type strain, Ben $70^{\mathrm{T}} \quad\left(=\mathrm{DSM} \quad 17518^{\mathrm{T}}=\mathrm{NCIMB}\right.$ $14127^{\mathrm{T}}$ ), was isolated from an activated sludge plant in Carrum, Victoria, Australia.

\section{Description of Tetrasphaera veronensis sp. nov.}

Tetrasphaera veronensis (ve.ro.nen'sis. L. nom. fem. adj. veronensis of Verona, Italy, from where the first isolates originated).

The phenotypic features of this species are those given by Blackall et al. (2000) for 'Candidatus N. limicola' strain Ver 1 , supplemented by the results of this study as follows. Catalase- and oxidase-positive. Poly- $\beta$-hydroxyalkanoate and polyphosphate production is positive. Isoprenoid quinones can not be detected in the type strain. The polar lipid pattern contains diphosphatidylglycerol and an unidentified phospholipid. Major cellular fatty acids contain iso- $\mathrm{C}_{16: 1}$.

The type strain, Ver $1^{\mathrm{T}}\left(=\mathrm{DSM} 17520^{\mathrm{T}}=\right.$ NCIMB $\left.14129^{\mathrm{T}}\right)$, was isolated from an activated sludge plant in Verona, Italy.

\section{ACKNOWLEDGEMENTS}

R. J.S. wishes to acknowledge the financial support of an Australian Research Council Large Grant to support this work, and J.-R.L. received a La Trobe University $\mathrm{PhD}$ scholarship.

\section{REFERENCES}

Beer, M., Seviour, E. M., Kong, Y., Cunningham, M., Blackall, L. L. \& Seviour, R. J. (2002). Phylogeny of the filamentous bacterium Eikelboom type 1851, and design and application of a 16S rRNA targeted oligonucleotide probe for its fluorescence in situ identification in activated sludge. FEMS Microbiol Lett 207, 179-183.

Blackall, L. L., Seviour, E. M., Cunningham, M. A., Seviour, R. J. \& Hugenholtz, P. (1994). "Microthrix parvicella" is a novel, deep branching member of the actinomycetes subphylum. Syst Appl Microbiol 17, 513-518. 
Blackall, L. L., Seviour, E. M., Bradford, D., Rossetti, S., Tandoi, V. \& Seviour, R. J. (2000). 'Candidatus Nostocoida limicola', a filamentous bacterium from activated sludge. Int J Syst Evol Microbiol 50, 703-709.

Butler, M. K., Wang, J., Webb, R. I. \& Fuerst, J. A. (2002). Molecular and ultrastructural confirmation of classification of ATCC 35122 as a strain of Pirellula staleyi. Int J Syst Evol Microbiol 52, 1663-1667.

Collins, M. D., Dorsch, M. \& Stackebrandt, E. (1989). Transfer of Pimelobacter tumescens to Terrabacter gen. nov. as Terrabacter tumescens comb. nov. and of Pimelobacter jensenii to Nocardioides as Nocardioides jensenii comb. nov. Int J Syst Bacteriol 39, 1-6.

Eikelboom, D. H. \& van Buijsen, H. J. J. (1983). Microscopic Sludge Investigation Manual, 2nd edn. Delft: TNO Research Institute of Environmental Hygiene.

Fergusson, K. M. \& Saint, C. P. (2000). Molecular phylogeny of Anabaena circinalis and its identification in environmental samples by PCR. Appl Environ Microbiol 66, 4145-4148.

Groth, I., Schumann, P., Martin, K., Schuetze, B., Augsten, K., Kramer, I. \& Stackebrandt, E. (1999). Ornithinicoccus hortensis gen. nov., sp. nov., a soil actinomycete which contains L-ornithine. Int J Syst Bacteriol 49, 1717-1724.

Groth, I., Schumann, P., Schütze, B., Augsten, K. \& Stackebrandt, E. (2002). Knoellia sinensis gen. nov., sp. nov. and Knoellia subterranea sp. nov., two novel actinobacteria isolated from a cave. Int J Syst Evol Microbiol 52, 77-84.

Gürtler, V. \& Stanisich, V. A. (1996). New approaches to typing and identification of bacteria using the $16 \mathrm{~S}-23 \mathrm{~S} \mathrm{rDNA}$ spacer region. Microbiology 142, 3-16.

Hanada, S., Liu, W.-T., Shintani, T., Kamagata, Y. \& Nakamura, K. (2002). Tetrasphaera elongata sp. nov., a polyphosphate-accumulating bacterium isolated from activated sludge. Int J Syst Evol Microbiol 52, 883-887.

Kämpfer, P. \& Wagner, M. (2002). Filamentous bacteria in activated sludge: current taxonomic status and ecology. In Encyclopedia of Environmental Microbiology, pp. 1287-1306. Edited by G. Bitton. New York: Wiley-Interscience.

Kämpfer, P., Terenius, O., Lindh, J. M. \& Faye, I. (2006). Janibacter anophelis sp. nov., isolated from the midgut of Anopheles arabiensis. Int J Syst Evol Microbiol 56, 389-392.

Kataoka, N., Tokiwa, Y., Tanaka, Y., Takeda, K. \& Suzuki, T. (1996). Enrichment culture and isolation of slow-growing bacteria. Appl Microbiol Biotechnol 45, 771-777.

Kong, Y., Nielsen, J. L. \& Nielsen, P. H. (2005). Identity and ecophysiology of uncultured actinobacterial polyphosphate-accumulating organisms in full-scale enhanced biological phosphorus removal plants. Appl Environ Microbiol 71, 4076-4085.

Kragelund, C., Nielsen, J. L., Thomsen, T. R. \& Nielsen, P. H. (2005). Ecophysiology of the filamentous Alphaproteobacterium Meganema perideroedes in activated sludge. FEMS Microbiol Ecol 54, 111-122.

Kumar, S., Tamura, K., Jakobsen, I.-B. \& Nei, M. (2001). MEGA2: molecular evolutionary genetics analysis software. Bioinformatics 17, 1244-1245.

Levantesi, C., Beimfohr, C., Geurkink, B., Rossetti, S., Thelen, K., Kroonman, J., Snaidr, J., van der Waarde, J. \& Tandoi, V. (2004). Filamentous Alphaproteobacteria associated with bulking in industrial wastewater treatment plants. Syst Appl Microbiol 27, 716-727.

Liu, J. R., McKenzie, C. A., Seviour, E. M., Webb, R. I., Blackall, L. L., Saint, C. P. \& Seviour, R. J. (2001). Phylogeny of the filamentous bacterium 'Nostocoida limicola' III from activated sludge. Int J Syst Evol Microbiol 51, 195-202.

Liu, J. R., Tanner, R. S., Schumann, P. \& 7 other authors (2002). Emended description of the genus Trichococcus, description of
Trichococcus collinsii sp. nov., and reclassification of Lactosphaera pasteurii as Trichococcus pasteurii comb. nov. and of Ruminococcus palustris as Trichococcus palustris comb. nov. in the low-G + C Gram-positive bacteria. Int J Syst Evol Microbiol 52, 1113-1126.

Martin, K., Schumann, P., Rainey, F. A., Schuetze, B. \& Groth, I. (1997). Janibacter limosus gen. nov., sp. nov., a new actinomycete with meso-diaminopimelic acid in the cell wall. Int J Syst Bacteriol 47, 529-534.

Martins, A. M. P., Pagilla, K., Heijnen, J. J. \& van Loosdrecht, M. C. M. (2004). Filamentous bulking sludge - a critical review. Water Res 38, 793-817.

Maszenan, A. M., Seviour, R. J., Patel, B. K. C., Rees, G. N. \& McDougall, B. M. (1997). Amaricoccus gen. nov., a gram-negative coccus occurring in regular packages and tetrads, isolated from activated sludge biomass, and descriptions of Amaricoccus veronensis sp. nov., Amaricoccus tamworthensis sp. nov., Amaricoccus macauensis sp. nov., and Amaricoccus kaplicensis sp. nov. Int J Syst Bacteriol 47, 727-734.

Maszenan, A. M., Seviour, R. J., Patel, B. K. C., Schumann, P. \& Rees, G. N. (1999). Tessaracoccus bendigoensis gen. nov., sp. nov., a Gram-positive coccus occurring in regular packages or tetrads, isolated from activated sludge biomass. Int J Syst Bacteriol 49, $459-468$.

Maszenan, A. M., Seviour, R. J., Patel, B. K. C., Schumann, P., Burghardt, J., Tokiwa, Y. \& Stratton, H. M. (2000). Three isolates of novel polyphosphate-accumulating Gram-positive cocci, obtained from activated sludge, belong to a new genus, Tetrasphaera gen. nov., and description of two new species, Tetrasphaera japonica sp. nov. and Tetrasphaera australiensis sp. nov. Int J Syst Evol Microbiol 50, 593-603.

McKerrow, J., Vagg, S., McKinney, T., Seviour, E. M., Maszenan, A. M., Brooks, P. \& Seviour, R. J. (2000). A simple HPLC method for analysing diaminopimelic acid diastereoisomers in cell walls of Gram-positive bacteria. Lett Appl Microbiol 30, 178-182.

Morse, R., Collins, M. D., O'Hanlon, K., Wallbanks, S. \& Richardson, P. T. (1996). Analysis of the $\beta^{\prime}$ subunit of the DNA-dependent RNA polymerase does not support the hypothesis inferred from $16 \mathrm{~S}$ rRNA analysis that Oenococcus oeni (formerly Leuconostoc oenos) is a tachytelic (fast-evolving) bacterium. Int J Syst Bacteriol 46, 1004-1009.

Prauser, H., Schumann, P., Rainey, F. A., Kroppenstedt, R. M. \& Stackebrandt, E. (1997). Terracoccus luteus gen. nov., sp. nov., an LL-diaminopimelic acid-containing coccoid actinomycete from soil. Int J Syst Bacteriol 47, 1218-1224.

Reasoner, D. J. \& Geldreich, E. E. (1985). A new medium for the enumeration and subculture of bacteria from potable water. Appl Environ Microbiol 49, 1-7.

Rossetti, S., Tomei, M. C., Nielsen, P. H. \& Tandoi, V. (2005). "Microthrix parvicella", a filamentous bacterium causing bulking and foaming in activated sludge systems: a review of current knowledge. FEMS Microbiol Rev 29, 49-64.

Schade, M., Beimfohr, C. \& Lemmer, H. (2002). Phylogenetic and physiological characterization of a "Nostocoida limicola"-like organism isolated from activated sludge. Water Sci Technol 46 (1-2), 91-97.

Schumann, P., Prauser, H., Rainey, F. A., Stackebrandt, E. \& Hirsch, P. (1997). Friedmanniella antarctica gen. nov., sp. nov., an LL-diaminopimelic acid-containing actinomycete from Antarctic sandstone. Int J Syst Bacteriol 47, 278-283.

Seo, P. S. \& Yokota, A. (2003). The phylogenetic relationships of cyanobacteria inferred from 16S rRNA, gyrB, rpoC1 and rpoD1 gene sequences. J Gen Appl Microbiol 49, 191-203. 
Seviour, E. M., Blackall, L. L., Christenson, C., Hugenholtz, P., Cunningham, M. A., Bradford, D., Stratton, H. M. \& Seviour, R. J. (1997). The filamentous morphotype Eikelboom type 1863 is not a single genetic entity. J Appl Microbiol 82, 411-421.

Seviour, R. J., Maszenan, A. M., Soddell, J. A., Tandoi, V., Patel, B. K. C., Kong, Y. \& Schumann, P. (2000). Microbiology of the 'Gbacteria' in activated sludge. Environ Microbiol 2, 581-593.

Seviour, R. J., Mino, T. \& Onuki, M. (2003). The microbiology of biological phosphorus removal in activated sludge systems. FEMS Microbiol Rev 27, 99-127.

Snaidr, J., Beimfohr, C., Levantesi, C., Rossetti, C., van der Waarde, J., Geurkink, B., Eikelboom, D., Lemaitre, M. \& Tandoi, V. (2002). Phylogenetic analysis and in situ identification of "Nostocoida limicola"-like filamentous bacteria in activated sludge from industrial wastewater treatment plants. Water Sci Technol 46 (1-2), 99-104.

Thompson, J. D., Gibson, T. J., Plewniak, F., Jeanmougin, F. \& Higgins, D. G. (1997). The CLUSTAL_X windows interface: flexible strategies for multiple sequence alignment aided by quality analysis tools. Nucleic Acids Res 25, 4876-4882.

Tsai, C.-S. \& Liu, W.-T. (2002). Phylogenetic and physiological diversity of tetrad-forming organisms in deteriorated biological phosphorus removal systems. Water Sci Technol 46 (1-2), 179-184.

Wilson, K. M., Schembri, M. A., Baker, P. D. \& Saint, C. P. (2000). Molecular characterization of the toxic cyanobacterium Cylindrospermopsis raciborskii and design of a species-specific PCR. Appl Environ Microbiol 66, 332-338.

Yoon, J.-H., Lee, K.-C., Kang, S.-S., Kho, Y. H., Kang, K. H. \& Park, Y.-H. (2000). Janibacter terrae sp. nov., a bacterium isolated from soil around a wastewater treatment plant. Int J Syst Evol Microbiol 50, 1821-1827.

Yoon, J.-H., Lee, H. B., Yeo, S.-H. \& Choi, J.-E. (2004). Janibacter melonis sp. nov., isolated from abnormally spoiled oriental melon in Korea. Int J Syst Evol Microbiol 54, 1975-1980. 